Revta brasil. Bot., São Paulo, V.24, n.2, p.123-134, jun. 2001

\title{
Population ecology of Paepalanthus polyanthus (Bong.) Kunth: demography and life history of a sand dune monocarpic plant
}

\author{
TÂNIA TARABINI CASTELLANI ${ }^{1,2}$, KARLA ZANENGA SCHERER $^{1}$ \\ and GISELLE DE SOUZA PAULA ${ }^{1}$
}

(received: June 9, 1999; accepted: January 11, 2001)

\begin{abstract}
Population ecology of Paepalanthus polyanthus (Bong.) Kunth: demography and life history of a sand dune monocarpic plant). Aspects of population dynamics and life history of Paepalanthus polyanthus (Bong.) Kunth, a sand dune monocarpic plant, were evaluated. A five year study was carried out on three permanent plots $(5 \mathrm{~m} \mathrm{x} 5 \mathrm{~m})$ in a sand dune slack at Joaquina beach, Santa Catarina State, Brazil. From December 1986 to June 1989, the population decreased due to the death of the post reproductive plants and a low emergence of seedlings. In June 1989, a great recruitment occurred, but no plants survived. The population re-established itself by 1990-1991. The emergence and high survival of seedlings depended on periods of high pluviosity. Nevertheless, the summer flooding and episodes of drought represented key factors in mortality. The birth and mortality rates varied among the areas. It is suggested that these differences are related with depth of the ground water and with vegetation cover at each site. Paepalanthus polyanthus can reproduce in the second year of life, but few plants do this. The chances of survival and reproduction increase with the size of the basal leaf rosette. Although the production of seeds increases with size, the risk of unexpected flooding, for instance, suggest that a great delay in reproduction might not be the most favorable strategy.
\end{abstract}

RESUMO - (Ecologia populacional de Paepalanthus polyanthus (Bong.) Kunth: demografia e estratégia de vida de uma planta monocárpica de dunas costeiras). Foram avaliados aspectos da dinâmica populacional e da estratégia de vida de Paepalanthus polyanthus (Bong.) Kunth, uma espécie monocárpica de dunas. As plantas presentes em três parcelas permanentes (5 m x $5 \mathrm{~m}$ ) foram monitoradas por cinco anos em uma área de baixada úmida de dunas na praia da Joaquina (Florianópolis, SC). De dezembro de 1986 a junho de 1989, a população decresceu devido à mortalidade das plantas pós-reprodutivas e a uma baixa emergência de plântulas. Em junho de 1989, ocorreu um recrutamento expressivo, mas nenhuma plântula sobreviveu. O restabelecimento populacional ocorreu apenas em 1990-1991. Tanto a germinação das sementes como a sobrevivência de plântulas dependem de períodos de alta pluviosidade. Entretanto, alagamentos no verão e períodos de déficit hídrico representam fatores-chaves de mortalidade. A natalidade e a mortalidade variaram entre as áreas. É sugerido que estas diferenças estejam relacionadas à profundidade do lençol freático e à cobertura vegetal em cada local. Paepalanthus polyanthus pode se reproduzir a partir do segundo ano de vida, mas poucas plantas o fazem. As chances de sobrevivência e reprodução aumentam com o tamanho da roseta foliar basal. Apesar da produção de sementes aumentar com o tamanho da planta, os riscos imprevisíveis de alagamento, por exemplo, sugerem que uma reprodução muito postergada pode não representar a melhor estratégia de vida.

Key words - Demography, monocarpic plant, sand dune slack, Paepalanthus polyanthus

\section{Introduction}

Many monocarpic species described as biennials present a minimum plant size necessary for reproduction. Since this minimum size may be reached in the second year of life or later, many of these species are called "facultative biennials" or "short-lived monocarpic species" (Werner 1975, Harper 1977, Meijden \& Waals-Kooi 1979, Boorman \& Fuller 1984, Kachi \& Hirose 1985, Klemow \& Raynal 1985, Jong \& Klinkhamer 1988). Waite (1984) reported that Plantago coronopus, a

1. Universidade Federal de Santa Catarina, Centro de Ciências Biológicas, Departamento de Ecologia e Zoologia, Caixa Postal 476, 88040-900 Florianópolis, SC, Brazil.

2. Corresponding author: ttcastel@ ccb.ufsc.br monocarpic species, could have different life cycles in different populations: annual, biennial or short-lived perennial. Van Baalen \& Prins (1983) also registered variations for Digitalis purpurea, which behaved as a short-lived polycarpic plant in initial succession and as a monocarpic with late reproduction in final succession stages.

Many short-lived monocarpic species show strong population reduction, and even local extinction, after favorable periods of colonization (Harper 1977, Jong \& Klinkhamer 1988). Different factors are determinants of these reductions: herbivory and seed predation (Meijden \& Waals-Kooi 1979, Jong \& Klinkhamer 1988, Klinkhamer et al. 1988); low germination rate, emergence and seedling survival due to climatic factors (Meijden \& Waals-Kooi 1979, Boorman \& Fuller 1984, Waite 1984, Kachi \& Hirose 1985, 
Klemow \& Raynal 1985, van Groenendael 1986, Jong \& Klinkhamer 1988); reduction of fecundity due to intraspecific competition (Klemow \& Raynal 1985); and interspecific interference along different succession stages and among different vegetation covers (van Baalen \& Prins 1983, Waite 1984, Klinkhamer \& Jong 1988). Several of these studies refer to sand dune populations, where the above factors were associated with population declines (Meijden \& Waals-Kooi 1979, Boorman \& Fuller 1984, Waite 1984, Kachi \& Hirose 1985, van Groenendael 1986, Jong \& Klinkhamer 1988, Klinkhamer \& Jong 1988, Klinkhamer et al. 1988).

Some monocarpic species, however, show stability for long periods of time (Jong \& Klinkhamer 1988). Klemow \& Raynal (1985) demonstrated that Echium vulgare populations remained constant and even increased in four years of strong drought in calcareous fields, while Picris hiercioides populations suffered strong reductions due to non-regeneration during this period.

The present study describes the population dynamics of Paepalanthus polyanthus (Bong.) Kunth in a sand dune field, evaluating: its life cycle; the population tendencies; the mortality risks and reproductive chances of established individuals; the recruitment of new individuals in the population; and the environmental factors possibly influencing this dynamics.

\section{Material and methods}

Study area - The study area was located in the dunes of Joaquina beach (approximately $27^{\circ} 36^{\prime} \mathrm{S}$ and $48^{\circ} 27^{\prime} \mathrm{W}$ ), Florianópolis, Santa Catarina State, Brazil, in a sand dune slack $500 \mathrm{~m}$ from the sea.

At this site, three permanent $5 \mathrm{~m} \times 5 \mathrm{~m}$ plots were randomly set, and were designated as Areas 1,2 and 3. These areas differed in topographic position (Castellani et al. 1995a). Areas 1 and 2 were located on lower sites, more humid and subject to floods. Area 3, on an upper site, was not flooded. Area 2 was plain; Area 1 was 3.4 to $23.5 \mathrm{~cm}$ above Area 2 in altitude, and Area 3 was 20 to $44 \mathrm{~cm}$ above Area 2 . The vegetation was mainly composed of Gramineae, Cyperaceae and Compositae species (Castellani et al. 1995a).

Climatic conditions and water table dynamics - The regional climate is characterized as Cfa, mesothermic humid (Souza et al. 1992). Climatic data for the years of study were obtained from the meteorological station of the Flight Protection Service (Florianópolis), $15 \mathrm{~km}$ from Joaquina beach. A climatic diagram was built according to Walter (1986), assuming potential evapotranspiration equivalent to $20 \mathrm{~mm}$ of precipitation for an average monthly temperature of $10{ }^{\circ} \mathrm{C}$. The climatic diagram shows the seasonal fluctuations in temperature, with a maximum mean of $24{ }^{\circ} \mathrm{C}$ to $26^{\circ} \mathrm{C}$ in December, January and February, and a minimum mean of $14{ }^{\circ} \mathrm{C}$ to $17{ }^{\circ} \mathrm{C}$ in June and July (figure 1). Reductions of precipitation usually occurred around the months of June, July and August. Drought episodes were registered in 1986, 1988, 1989 and 1991. The driest year was 1988, with strong water deficits in July, August and November. The most humid years were 1990 and 1991, with higher precipitation in February 1990 and November 1991 (figure 1).

After 1986, a first flooding (water table emergence) occurred in summer 1990, covering Area 2 totally and half of Area 1. This flooding lasted from January until April in Area 1 and until May in Area 2. The water table level reached from 10 to $15 \mathrm{~cm}$ above the sand surface. In November of 1991, a new flood occurred in both areas. This flooding lasted approximately one month in Area 1, while Area 2 still presented a thin layer of water in December 1991. Area 3 was never flooded.

Studied species - Paepalanthus polyanthus (Bong.) Kunth (Eriocaulaceae) is a monocarpic, monoecious species (d'Eça-Neves \& Castellani 1994) which occurs in upland fields and in coastal sand dunes (Moldenke \& Smith 1976). Waechter (1985) refers to this species as "endangered" in the coastal dunes of southern Brazil due to human activity. The Paepalanthus polyanthus growth-form is a basal rosette with linear lanceolate leaves forming umbels with a high number of capitula (Moldenke \& Smith 1976). At the study site, the dunes of Joaquina beach, Castellani \& d'Eça-Neves (2000) estimated an average production of about 1600 capitula developed per plant, with an average of about 9000 seeds. In this sand dune, flowering occurs from July to January, with a peak in November, and fruiting starts in September. In December and January, most of the reproductive plants disperse their capitula. The capitulum represents the unit of dispersion, and most of them fall down near the reproductive plant (T.T. Castellani, unpublished data). A minimum rosette diameter of $12 \mathrm{~cm}$ for reproduction with subsequent death of the post-reproductive plants was also observed (d'Eça-Neves \& Castellani 1994).

At Joaquina beach, Paepalanthus polyanthus occurs in sand dune slacks. The population is described as having a discontinuous distribution, forming dense groups, conspicuous during the reproductive period (Moldenke \& Smith 1976).

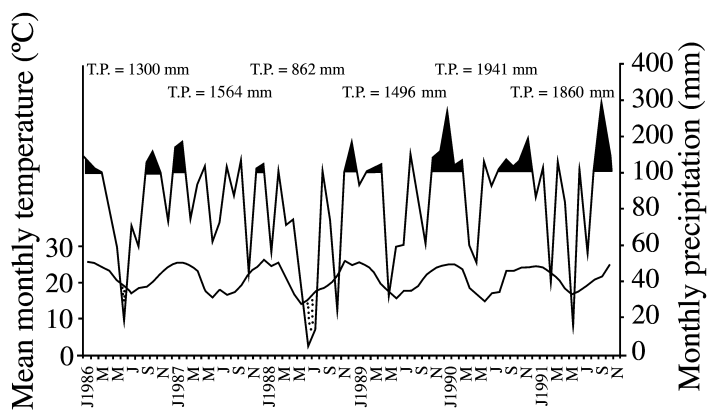

Figure 1. Climatic diagram during the study period, Florianópolis, SC, Brazil. Periods of high humidity $(\mathrm{P}>100 \mathrm{~mm})(\square)$, moist period $(\mathrm{T}<\mathrm{P}<100 \mathrm{~mm})(\square)$ and periods of drought $(\mathrm{T}>\mathrm{P})(\vdots \vdots)$. P. precipitation, T. temperature and T.P. total yearly precipitation. 
Castellani et al. (1996) described an aggregate pattern for the population, with a low density at drier and higher sites of the slack, as well as at the more inundated sites. Higher densities occur at intermediate topographic sites.

Procedures - Paepalanthus polyanthus plants present in the plots were accompanied from December 1986 to December 1991. Each $25 \mathrm{~m}^{2}$ plot, subdivided into twenty-five $1 \mathrm{~m} \times 1 \mathrm{~m}$ subsquares, was sampled for: counting, marking and mapping of new individuals; mortality evaluation of the pre-established plants; determination of the diameter of the basal rosette; and determination of the phenological phase of the individuals (vegetative or reproductive). Plants already established in December 1986 were marked with plastic tag tied around the rosette. Seedlings were marked with numbered wooden sticks $(6.5 \mathrm{~cm}$ high and diameter of $2.0 \mathrm{~mm}$ ) placed beside each plant. Some seedlings germinated in aggregation due to badly dispersed capitula. Those "groups" were marked with wooden sticks $(11.5 \mathrm{~cm} \times 1 \mathrm{~cm})$ in order to follow the seedlings' survival. The intervals among samplings were one or two months in the first four years and three months in 1991.

Data related to plant vigor and sand burial were noted. The occurrence of herbivores affecting this population of Paepalanthus polyanthus was described in Castellani et al. (1995b). In 1989, the percentage of damage in seedlings rosette was estimated visually and the plants were accompanied to evaluate the survival rates.

The seedlings registered in each sampling period were treated as different cohorts. In 1989, each sampling lasted five days, but in 1990/1991 it lasted around 20 days because of the high number of seedlings.

In December 1989 and December 1990, the point quadract method (Greig-Smith 1983) was used for the vegetation cover analyses. An iron pin (1 m long and $0.5 \mathrm{~cm}$ in diameter) was vertically driven into the ground in a regular manner, 2500 times in each area. The number of times the pin intercepted at least one species associated with Paepalanthus polyanthus was registered.

In December 1989, we evaluated the relationship between seedling density and percentage cover in each subsquare of $1 \mathrm{~m}^{2}$ in Area 1. Pearson correlation was applied to these relationships after arcsine transformation (Zar 1974). Differences among plant survival were evaluated using G-test (Sokal \& Rohlf 1979).

\section{Results}

Synthesis of the population fluctuations Paepalanthus polyanthus (Bong.) Kunth showed great density fluctuation throughout the five years in the study areas. From December 1986 to December 1988 , the population reduced due to low emergence of seedlings and loss of pre-established individuals (table 1). In Area 1, which had the highest density at the beginning of the study, the post-reproductive mortality was the main cause of death of pre-established individuals. In Areas 2 and 3, the mortality of plants in vegetative phase was
Table 1. Population flux of Paepalanthus polyanthus from December 1986 to December 1991, expressed in numbers of plants in three permanent plots of $25 \mathrm{~m}^{2}$ in a sand dune slack at Joaquina beach (SC, Brazil).

Area 1 Area 2 Area 3

December 1986 to December 1987

vegetative plants in Dec. 1986

reproduced in 1987

$\begin{array}{rrr}259 & 55 & 45 \\ 118 & 15 & 11 \\ 20 & 17 & 17 \\ 121 & 23 & 17 \\ 10 & 10 & 3 \\ 1 & 6 & 0 \\ & & \\ 122 & 29 & 17 \\ 83 & 12 & 8 \\ 18 & 2 & 4 \\ 21 & 15 & 5 \\ 1 & 0 & 0 \\ 0 & - & -\end{array}$

December 1988 to December 1989

vegetative plants in Dec. 1988

reproduced in 1989

died without reproducing in 1989

survived until Dec.1989

seedlings registered in 1989

seedlings alive in Dec.1989

$\begin{array}{rrr}21 & 15 & 5 \\ 6 & 5 & 3 \\ 15 & 6 & 2 \\ 0 & 4 & 0 \\ 234 & 1646 & 0 \\ 7 & 214 & -\end{array}$

December 1989 to December 1990

vegetative plants in Dec. 1989

reproduced in 1990

died without reproducing in 1990

survived until Dec.1990

seedlings registered in 1990

seedlings alive in Dec.1990

$\begin{array}{rrr}7 & 218 & 0 \\ 0 & 0 & - \\ 7 & 218 & - \\ 0 & 0 & - \\ 3356 & 473 & 2985 \\ 2487 & 405 & 2290\end{array}$

December 1990 to December 1991

vegetative plants in Dec. 1990

$2487 \quad 405 \quad 2290$

reproduced in 1991

died without reproducing in 1991

survived until Dec.1991

$\begin{array}{lll}2 & 3 & 2\end{array}$

seedlings registered in 1991

617

$139 \quad 1171$

seedlings alive in Dec.1991

$\begin{array}{lll}1868 & 263 & 1117\end{array}$

$\begin{array}{lll}65 & 39 & 38\end{array}$

December 1991

$28 \quad 23 \quad 22$


proportionally higher $(\mathrm{G}$-test $=25.14 ; \mathrm{gl}=2$; $\mathrm{p}<0.001$ ) (table 1).

In December 1989, no pre-established individuals were alive in Areas 1 and 3. In Area 2, the four pre-established plants alive died during the flooding of January 1990 (table 1).

In 1987, 23 seedlings were registered in the three areas, and in 1988 no seedlings emerged. In 1989, seedlings occurred in Areas 1 and 2, but not in Area 3 (table 1). Germination was detected in June, after autumn rainfall, occurring until November. In December 1989, 3\% and 13\% of the registered seedlings were alive in Areas 1 and 2, respectively, but no seedling survived the summer flooding of 1990 (table 1, see patterns of seedling survival and mortality risks).

After this summer flooding, massive seedling recruitment re-established the population, which presented plants in reproduction in December 1991 (table 1). Most seedlings were registered in autumn 1990: from April onwards in Areas 1 and 3, and from May onwards in Area 2, where seedling emergence was less abundant. The germination process was continuous until April 1991, with few seedlings registered in 1991 (table 1).

In Areas 1 and 3, some seedlings germinated in "groups". In Area 1, 31 groups were registered (Mean $=3.32$ seedlings.group ${ }^{-1}$; standard deviation $=1.11 ;$ minimum $=2$ and maximum $=7$ ), and in Area
3, 159 groups were noted $($ Mean $=5.36$ seedlings.group ${ }^{-1} ;$ standard deviation $=1.95$; minimum $=2$ and maximum $=13$ ).

Some plants recruited in 1990 and $1991(n=71)$ formed new leaf rosettes, through sprouting, that were quantified as new individuals for demographic census. About $85 \%$ of these plants produced one new rosette and $15 \%$ two rosettes. Plants sprouted with at least four months of development and diameters between 3 to $9 \mathrm{~cm}$.

The re-establishment of Paepalanthus polyanthus population presented an increase until December 1990, with a decrease in 1991 (table 1). The flooding in November 1991 was a mortality factor in Areas 1 and 2; Area 3 was more affected by periods of rainfall reduction (see patterns of seedling survival and mortality risks).

Mortality risks and reproductive chances of pre-established plants - Individuals from December 1986 showed that the probability of reproduction tends to increase with the diameter of the basal leaf rosette. Also, the probability of death tends to decrease in larger plants. This pattern of mortality, however, was not clear in 1989 , and the mortality rates were higher in all size classes (table 2).

Vegetation cover and seedling emergence - From December 1986 to December 1989, the sand ground in Area 1, wich had earlier been densely occupied by Paepalanthus polyanthus, became bare after the

Table 2. Number of vegetative plants of Paepalanthus polyanthus alive in December 1986, 1987 and $1988(\mathrm{~N})$ and chance of reproducing $(\% \mathrm{R})$, survival as a vegetative plant $(\% \mathrm{~V})$ or dying without reproducing $(\% \mathrm{D})$, presented during subsequent years. Plants are distributed in size classes of foliar rosette diameter $(\mathrm{cm})$.

\begin{tabular}{|c|c|c|c|c|c|c|c|c|c|c|c|c|}
\hline $\begin{array}{l}\text { Size classes } \\
(\mathrm{cm})\end{array}$ & $\begin{array}{c}\mathrm{N} \\
\text { (Dec. 86) } \\
\end{array}$ & $\% \mathrm{R}$ & $\begin{array}{l}1987 \\
\% \mathrm{~V} \\
\end{array}$ & $\% \mathrm{D}$ & $\begin{array}{c}\mathrm{N} \\
\text { (Dec. 87) } \\
\end{array}$ & $\% \mathrm{R}$ & $\begin{array}{l}1988 \\
\% \mathrm{~V} \\
\end{array}$ & $\% \mathrm{D}$ & $\begin{array}{c}\mathrm{N} \\
\text { (Dec. 88) } \\
\end{array}$ & $\% \mathrm{R}$ & $\begin{array}{l}1989 \\
\% \mathrm{~V} \\
\end{array}$ & $\% \mathrm{D}$ \\
\hline$<3$ & 12 & 0 & 50 & 50 & 1 & 0 & 0 & 100 & 0 & - & - & - \\
\hline $3-6$ & 47 & 4 & 49 & 47 & 7 & 0 & 57 & 43 & 1 & 0 & 0 & 100 \\
\hline $6-9$ & 68 & 4 & 78 & 18 & 15 & 7 & 60 & 33 & 1 & 0 & 100 & 0 \\
\hline $9-12$ & 67 & 28 & 63 & 9 & 25 & 16 & 60 & 24 & 2 & 0 & 0 & 100 \\
\hline $12-15$ & 83 & 57 & 37 & 6 & 41 & 73 & 20 & 7 & 7 & 14 & 14 & 72 \\
\hline $15-18$ & 47 & 85 & 13 & 2 & 33 & 79 & 9 & 12 & 13 & 31 & 15 & 54 \\
\hline $18-21$ & 27 & 93 & 0 & 7 & 30 & 87 & 7 & 7 & 8 & 38 & 0 & 62 \\
\hline $21-24$ & 5 & 100 & 0 & 0 & 9 & 100 & 0 & 0 & 2 & 100 & 0 & 0 \\
\hline $24-27$ & 3 & 100 & 0 & 0 & 4 & 100 & 0 & 0 & 5 & 60 & 0 & 40 \\
\hline $27-30$ & 0 & - & - & - & 3 & 100 & 0 & 0 & 1 & 100 & 0 & 0 \\
\hline $30-33$ & 0 & - & - & - & 0 & - & - & - & 1 & 0 & 0 & 100 \\
\hline
\end{tabular}


removal of dead plants by the wind. The seedlings which emerged in this area in 1989 were registered in greater number in the subsquares with higher plant cover, with no germination on bare sand ground $(\mathrm{r}=0.71, \mathrm{p}<0.001, \mathrm{n}=25)$.

A relationship between emergence of seedlings and plant cover may also be suggested when the sampling areas are compared. In 1989, no seedling occurred in Area 3, which presented 33.80\% of plant cover. On the other hand, in Areas 1 and 2, where seedlings emerged, the plant cover was $50.36 \%$ and $70 \%$, respectively. Despite the lower number of reproductive plants in 1988 (table 1), Area 2 presented higher emergence and survival of seedlings in 1989.

In 1990, emergence of seedlings occurred in all areas. The percentage cover increased in Areas 1, 2 and 3 , attaining values of $77 \%, 78 \%$ and $64 \%$, respectively.

Patterns of seedling survival and mortality risks Cohorts of 1989 showed survival curves of non-linear pattern. Higher mortality risks occurred in November 1989, in January 1990, and in the initial establishment phase for Cohorts 1 and 2 (figure 2), which emerged in periods of rainfall reduction. In Cohort 1 in Area 2, the overlap among seedlings $(\mathrm{n}=246)$ caused high mortality risk ( $c a .72 \%)$. These seedlings emerged from seeds presented in capitula of one umbel. This umbel fell near the reproductive plant and the capitula did not disperse. The mortality seemed to be associated with pluviosity reduction in November 1989 and with flooding in January 1990.

Seedlings of Paepalanthus polyanthus were damaged by the leaf-cutting ant Acromyrmex striatus (Hymenoptera: Formicidae). These ants occurred in Area 2, and the highest percentage of
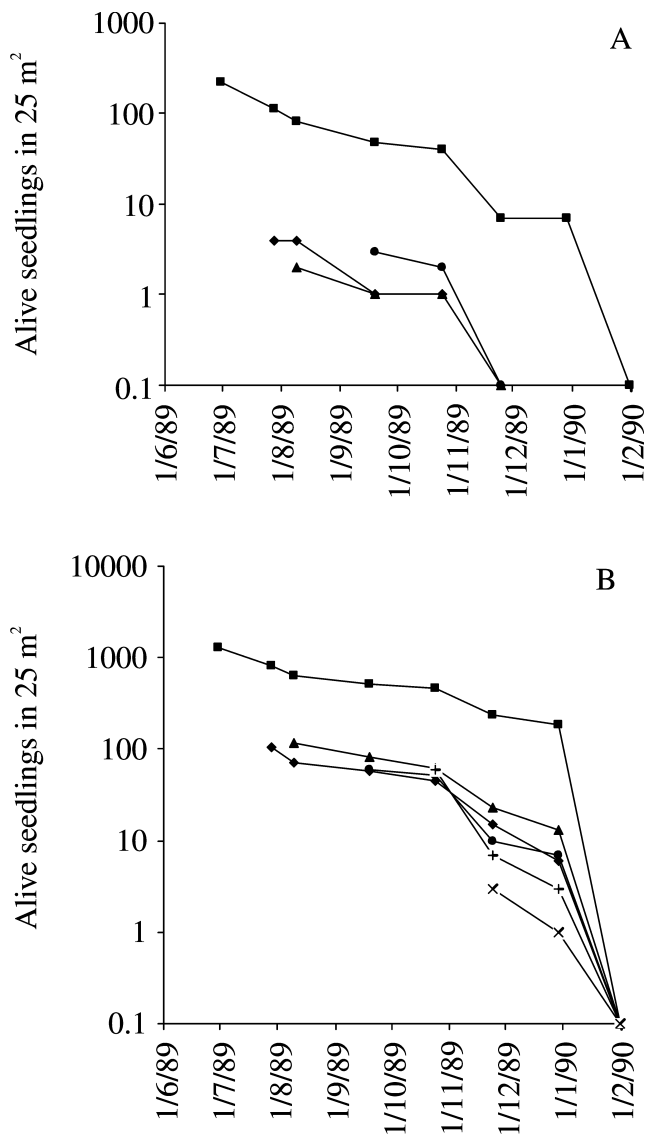

Figure 2. Survivorship curves for cohorts of Paepalanthus polyanthus seedlings in 1989, in sand dune slack, Joaquina beach, Florianópolis, SC, Brazil. A. Area 1, B. Area 2. Cohort 1 (ם), Cohort $2(\bullet)$, Cohort $3(\boldsymbol{\Delta})$, Cohort $4(\bullet)$, Cohort $5(+)$ and Cohort 6 (x). Cohorts 5 and 6 , with 1 seedling each, were not plotted in Area 1. No seedlings emerged in Area 3 in 1989.

Table 3. Number of plants of Paepalanthus polyanthus herbivored by Acromyrmex striatus (Hymenoptera: Formicidae) in Area 2 $\left(25 \mathrm{~m}^{2}\right)$ throughout 1989.

\begin{tabular}{lcccc}
\hline Date & Alive plants & Herbivored plants & Average foliar damage (\%) & $\begin{array}{c}\text { Herbivored plants dead } \\
\text { until the next sampling }\end{array}$ \\
\hline June 1989 & 1303 & 33 & 4 & 7 \\
July 1989 & 920 & 5 & 1 & 0 \\
August 1989 & 831 & 4 & 1 & 0 \\
September 1989 & 715 & 3 & 1 & 0 \\
October 1989 & 685 & 55 & 40 & 30 \\
November 1989 & 295 & 10 & 10 & 0 \\
December 1989 & 214 & 7 & 15 & 7 \\
\hline
\end{tabular}


damage was registered in October 1989. These seedlings, which were herbivored in October 1989, showed low survival until the next sampling (table $3)$.

Cohorts of 1990/1991 showed a higher establishment success (figure 3). The proportion of isolated seedlings alive in December 1991 differed among the three areas $(\mathrm{G}$-test $=119.42 ; \mathrm{gl}=2$; $\mathrm{p}<0.001)$. In Area 1, from the total of seedlings registered in 1990 and $1991,54.84 \%(n=3233)$ were alive in December 1991; in Area 2, 55.35\% ( $\mathrm{n}=495)$ were alive and in Area 3, a lower proportion was presented, $40.09 \%(\mathrm{n}=2135)$.

The emergence of seedlings in Area 2 was later (figure 3B) and the first cohort emerged in a soil still flooded. In Area 1 and 2 (figure 3A, B), the flooding in November 1991 acted as mortality factor. In December 1991, $18.79 \%$ of deaths in Area 1 $(\mathrm{n}=165)$ were caused by flooding, which affected the leaves of other 503 plants. In Area 2, this flooding caused $81.60 \%$ of deaths $(n=125)$ and damaged another 154 plants. In Area 3, mortality rates in summer 1991 were more expressive (figure 3C). In April 1991, 75\% of the registered deaths $(n=460)$ were caused by desiccation. In Area 1 and 3, hydric reductions in September caused desiccation in many plants.

In Areas 1 and 3, sand burial affected some seedlings (table 4). Usually caused by the wind, sand burial in September 1991 was in part caused by the nest-building of Dorymyrmex sp. (Hymenoptera: Formicidae).

In December 1991, eight plants from the first cohorts reproduced: three plants in Area 1, with rosette diameter between 21 and $24 \mathrm{~cm}$ and age of one year and five months to one year and eight months; three plants in Area 2, with rosette diameters between 16 and $17.5 \mathrm{~cm}$ and ages of one year and four months to one year and seven months; and two plants in Area 3, with rosette diameters of 19 and $20 \mathrm{~cm}$ and ages of one year and five months.

Seedlings emerged in group (figure 4) also presented lower proportion of survivors in Area 3 (G-test $=249.16 ; \mathrm{gl}=1 ; \mathrm{p}=0.001)$. From the seedlings which emerged in groups in 1990 and $1991,59 \%(\mathrm{n}=103)$ and $29.80 \%(\mathrm{n}=839)$ were alive in Area 1 and 3, respectively, in December 1991. In Area 3, the proportion of plants alive in
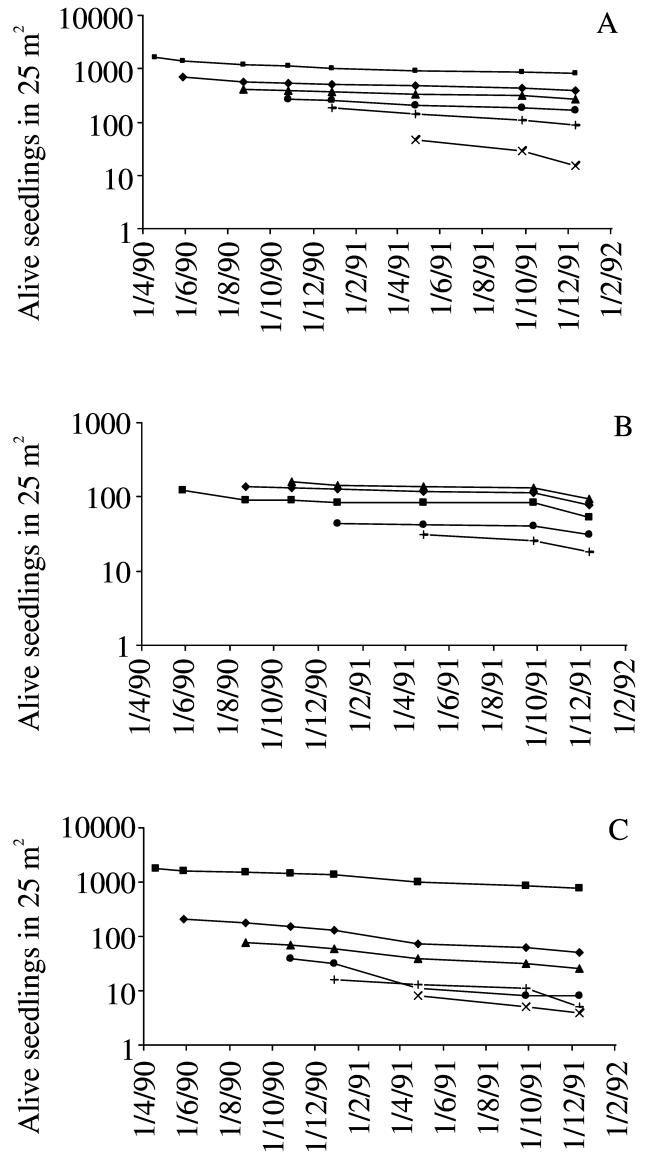

Figure 3. Survivorship curves for cohorts of Paepalanthus polyanthus seedlings in 1990-1991, in sand dune slack, Joaquina beach, Florianópolis, SC, Brazil. A. Area 1, B. Area 2, C. Area 3. Cohort $1(\square)$, Cohort $2(\bullet)$, Cohort $3(\boldsymbol{\Delta})$, Cohort $4(\bullet)$ Cohort 5 $(+)$ and Cohort $6(x)$. Cohort 6 , with 1 seedling, was not plotted in Area 2. Cohorts 7, with 2 and 3 seedlings, were not plotted in Area 1 and 3, respectively.

December 1991 was lower for grouped seedlings than that of isolated seedlings (G-test $=22.25 ; \mathrm{gl}=1$; $\mathrm{p}<0.001)$. Higher seedling losses occurred in summer 1991 and from September to December 1991 (figure 4B). Entire groups became desiccated and were removed by wind. Group-seedlings were affected by sand burial in the Area 3 but not in Area 1 (table 4).

Variation in the population structure - The size-frequency distribution of vegetative plants in December 1987 and 1988 shows a relative increase of individuals in intermediate and large-size classes 
Table 4. Plants of Paepalanthus polyanthus buried by sand throughout 1990 and 1991 in three permanent plots of $25 \mathrm{~m}^{2}$ in a sand dune slack at Joaquina beach (Florianópolis, SC, Brazil). Plants are differentiated in relation to pattern of germination as isolated or grouped plants.

\begin{tabular}{|c|c|c|c|c|c|c|}
\hline & \multicolumn{4}{|c|}{ Isolated plants } & \multicolumn{2}{|c|}{ Grouped plants } \\
\hline & $\begin{array}{l}\text { Plants buried } \\
\text { by sand }\end{array}$ & $\begin{array}{r}\text { Plants dead } \\
\text { after burial }\end{array}$ & $\begin{array}{c}\text { Plants buried by } \\
\text { ant-nest } \\
\text { construction } \\
\end{array}$ & $\begin{array}{l}\text { Plants dead after } \\
\text { burial by ant- } \\
\text { nest construction }\end{array}$ & $\begin{array}{l}\text { Plants buried } \\
\text { by sand }\end{array}$ & $\begin{array}{l}\text { Plants dead } \\
\text { after burial }\end{array}$ \\
\hline \multicolumn{7}{|l|}{ Area 1} \\
\hline April 1990 & 0 & - & 0 & - & 0 & - \\
\hline May 1990 & 8 & 1 & 0 & - & 0 & - \\
\hline August 1990 & 53 & 6 & 4 & 0 & 0 & - \\
\hline October 1990 & 2 & 0 & 0 & - & 0 & - \\
\hline December 1990 & 26 & 2 & 0 & - & 0 & - \\
\hline April 1991 & 4 & 1 & 0 & - & 0 & - \\
\hline September 1991 & 25 & 6 & 21 & 9 & 0 & - \\
\hline December 1991 & 7 & 3 & 7 & 3 & 0 & - \\
\hline \multicolumn{7}{|l|}{ Area 2} \\
\hline April 1990 & 0 & - & 0 & - & 0 & - \\
\hline May 1990 & 0 & - & 0 & - & 0 & - \\
\hline August 1990 & 0 & - & 0 & - & 0 & - \\
\hline October 1990 & 0 & - & 0 & - & 0 & - \\
\hline December 1990 & 1 & 0 & 1 & 0 & 0 & - \\
\hline April 1991 & 0 & - & 2 & 1 & 0 & - \\
\hline September 1991 & 0 & - & 0 & - & 0 & - \\
\hline December 1991 & 0 & - & 0 & - & 0 & - \\
\hline \multicolumn{7}{|l|}{ Area 3} \\
\hline April 1990 & 0 & - & 0 & - & 1 & 0 \\
\hline May 1990 & 26 & 8 & 1 & 0 & 3 & 0 \\
\hline August 1990 & 38 & 6 & 0 & - & 13 & 0 \\
\hline October 1990 & 7 & 6 & 0 & - & 7 & 0 \\
\hline December 1990 & 10 & 2 & 0 & - & 4 & 0 \\
\hline April 1991 & 82 & 46 & 1 & 0 & 36 & 9 \\
\hline September 1991 & 67 & 21 & 18 & 1 & 46 & 6 \\
\hline December 1991 & 15 & 7 & 4 & 0 & 15 & 12 \\
\hline
\end{tabular}

in relation to December 1986 (figure 5). In the absence of recruitment, there was a reduction in small-size plants, in consequence of their mortality and of the growth of those that survived. The mortality of post-reproductive individuals resulted in a low frequency of large-sized individuals.

The distribution pattern of December 1989 and 1990, and even the pattern of December 1991, reflects the regeneration that occurred in these years, being the highest frequency of individuals with diameter between 3 to $6 \mathrm{~cm}$.

\section{Discussion}

The density variations observed throughout these five years in the Paepalanthus polyanthus 

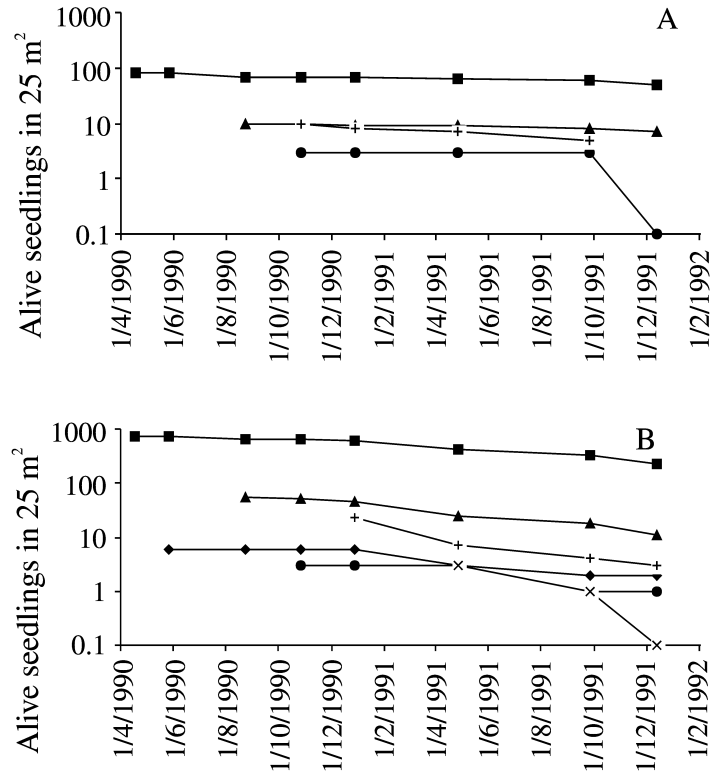

Figure 4. Survivorship curves for cohorts of Paepalanthus polyanthus seedlings emerging in groups in 1990-1991, in sand dune slack, Joaquina beach, Florianópolis, SC, Brazil. A. Area 1, B. Area 3. Cohort $1(\square)$, Cohort $2(\bullet)$, Cohort $3(\boldsymbol{\Delta})$, Cohort $4(\bullet)$, Cohort $5(+)$ and Cohort $6(\mathrm{x})$.

(Bong.) Kunth population are common to several short-lived monocarpic species (Harper 1977, Jong \& Klinkhamer 1988). In some dune plants, low recruitment of seedlings is in part explained by predation in the pre-dispersal phase (Watkinson \& Harper 1978, Klinkhamer et al. 1988). This did not seem to have occurred in Paepalanthus polyanthus. Reproductive plants were present in all areas in the low regeneration period, with an average seed set of about 9000 per plant (Castellani \& d'Eça-Neves 2000). Flower predators can cause losses in 5\% of seed production in Paepalanthus polyanthus, and losses of $12 \%$ can occur in cases of umbel abortion caused by borer caterpillar (Castellani \& d'Eça-Neves 2000). However, these values seem to be low to cause expressive reduction in the seed production of this population.

In Paepalanthus polyanthus, the population fluctuation is related to climatic factors, especially to water availability, which acts on germination and survival of plants. Other monocarpic dune plants show population fluctuations associated with climatic factors. In Lactuca virosa, germination increases with fall humidity, and seedling mortality increases in years with higher drought stress (Boorman \& Fuller 1984). Populations of Plantago lanceolata are subjected to strong reductions due to drought (van Groenendael 1986). Reductions in Cirsium vulgare and Cynoglosum officinale are caused by seed predation and drought stress, which reduce seedling survival (Jong \& Klinkhamer 1988). Not only in monocarpic species, but also in other sand dune plants, low pluviosity causes population decline (Watkinson \& Harper 1978, Ernst 1981, Waite 1984). Drought stress is a factor that controls the germination, emergence and survival of seedlings (Meijden \& Waals-Kooi 1979), survival of established and reproductive plants (Ernst 1981, d'Eça-Neves \& Castellani 1994), and ramet birth and death (Huiskes \& Harper 1979, Costa \& Seeliger 1988).

In Paepalanthus polyanthus, differences of seedling emergence among areas can also be related to available water. Area 3, at a higher topographic site and never flooded, presented seed germination only in the most humid period. Low germination in Area 2 in 1990, however, could suggest a reduction in soil seed bank, due to previous germination. In other sand dune species, differences among habitats are also related to higher frequency of seedling establishment in more humid areas (Huiskes \& Harper 1979, Costa et al. 1988).

In sand dune slacks, the depth of the water table acts over the initial phases of the life cycle, determining the percentages of germination and establishment of seedlings (Schat \& Scholten 1985). In Paepalanthus polyanthus, the emergence of the water table seems to favor germination, on one hand, and acts as a mortality factor, on the other. The role of such inundations as mortality agents varies in relation to the duration of flooding and flooding level.

Flooding acted in a distinct way among areas. In Area 2, higher risks of population reduction might occur by successive flooding. Flooding causes pre-reproductive deaths, which can reduce seed production. This can make the population dependent upon adjacent sources of seeds. The fact that Paepalanthus species tend to disperse at low distance (Figueira 1998) can limit the potential of its population reestablishment. The longevity of seeds 

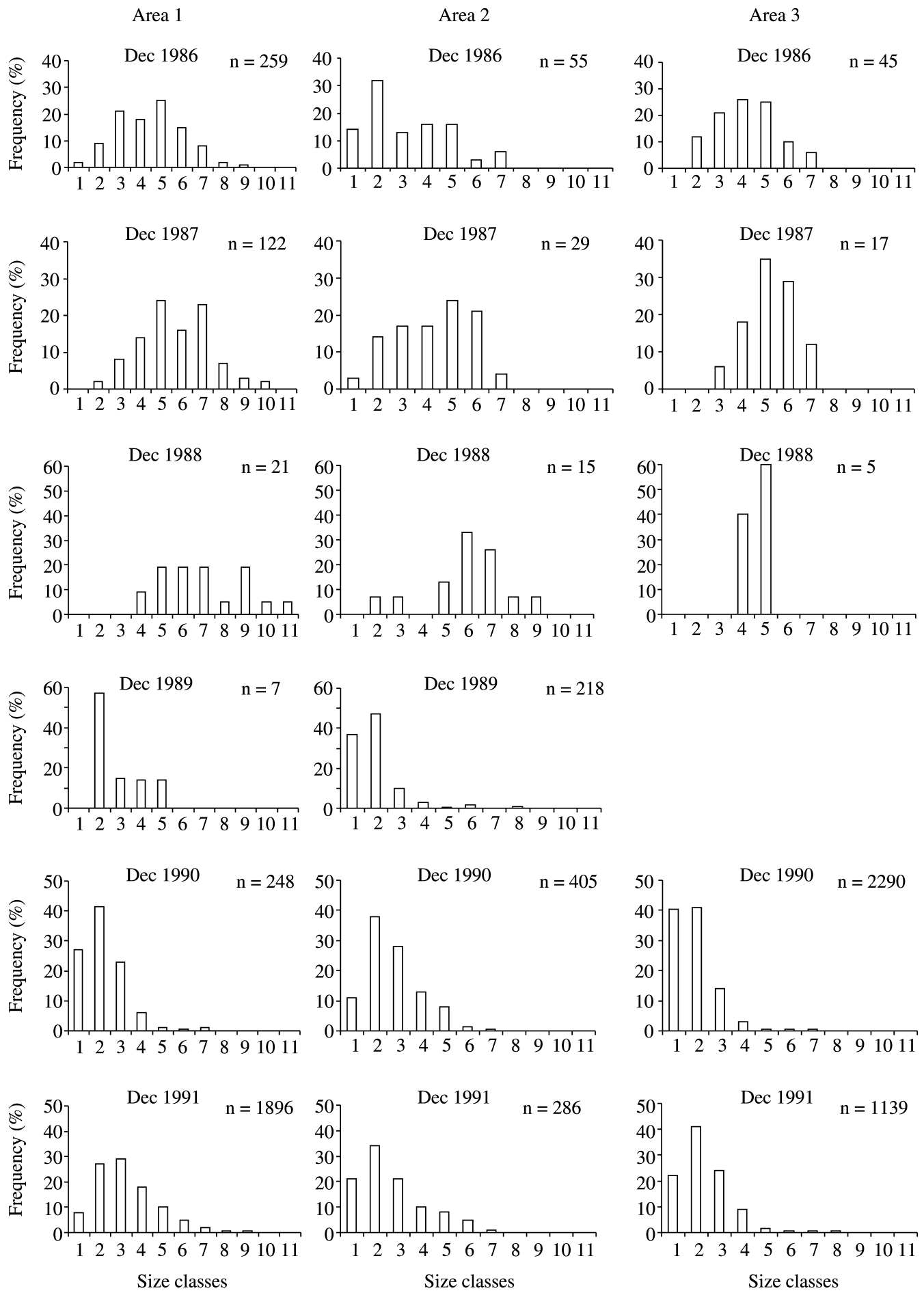

Figure 5. Population structure of Paepalanthus polyanthus in Areas 1, 2 and 3 from December 1986 to December 1991 in three permanent plots of $25 \mathrm{~m}^{2}$ in a sand dune slack at Joaquina beach, Florianópolis, SC, Brazil. The size classes are based on the diameter of the foliar rosette: $1(<3 \mathrm{~cm}), 2(3-6 \mathrm{~cm}), 3(6-9 \mathrm{~cm}), 4(9-12 \mathrm{~cm}), 5(12-15 \mathrm{~cm}), 6(15-18 \mathrm{~cm}), 7(18-21 \mathrm{~cm}), 8(21-24 \mathrm{~cm}), 9(24-27 \mathrm{~cm}), 10$ $(27-30 \mathrm{~cm})$ and $11(30-33 \mathrm{~cm})$. 
of Paepalanthus polyanthus in soil is not known. A permanent seed bank could represent a good strategy for this species. Certainly, this aspect needs to be investigated.

The low emergence of seedlings of Paepalanthus polyanthus in less covered areas may simply reflect a humidity mosaic or other survival risk in bare areas such as seed desiccation or seed burial (Ernst 1981, Buckley 1982). Although no study has been carried out on the germination of this Paepalanthus species, the requirement of light by seeds of Paepalanthus speciosus (Carvalho \& Ribeiro 1994) suggests no germination under buried conditions. Also, Paepalanthus polyanthus presents small seeds, with a diameter of approximately $0.5 \mathrm{~mm}$. According to Buckley (1982), small seeds offer little chance of seedling emergence when buried by sand. This author suggests that seed size might have an important role in the population dynamics of dune plants: small-seed species would present reductions in dry periods and regeneration under existing vegetation, and large-seed species would be more independent in relation to the physical environment. Klemow \& Raynal (1985) observed higher emergence and establishment of Picris hieracioides seedlings in areas of denser vegetation. Jong \& Klinkhamer (1988) show that the survival of Cirsium vulgare and Cynoglossum officinale is lower in more exposed habitats, due to desiccation.

Burial may also act as a mortality factor in seedlings, as registered in Area 3. Burial may be achieved either by the wind or by the activities of certain ants.

The seedlings emerged in groups had greater mortality risks by desiccation effects and bad fixation on sand ground, due to bad capitula dispersion. Then, capitula dispersion may increase seedling survival, just by reducing seedling overlapping.

The role of herbivores in the population dynamics of Paepalanthus polyanthus is not clear. Castellani et al. (1995b) described the caterpillars of Junonia evarete (Lepidoptera: Nymphalidae) as the main herbivores of established plants of Paepalanthus polyanthus. The mortality of damaged plants, however, was higher in periods of drought stress and in plants injured for subsequent years.
Also, seedlings damaged by Acromyrmex striatus (Hymenoptera: Formicidae) showed higher mortality rates in drought stress periods, when an expressive mortality of non-damaged seedlings also occurred. Then, it is not clear if herbivory is the main cause of such deaths.

In relation to the temporal variation of the population structure, the "J-reverse" pattern observed in 1989 and 1990/1991 reflected the regeneration occurring in those years. In 1990/1991, the observed structure in Area 3 may also suggest a lower growth rate. In this area, the frequency of young plants in the smallest size-class was higher in relation to the other areas. A slow pattern of initial growth might contribute to a size distribution of the "J-reversed" type, since the individuals remain in this phase for a long period (Hutchings 1986).

In Paepalanthus polyanthus, as well as in other short-lived monocarpic species (Werner 1975, Jong $\&$ Klinkhamer 1988), the mortality risks were lower in larger plants. The size for reproduction can be reached in the second year of life or later, and the probability of reproduction increased with plant size, as did the production of floral capitula (Castellani 1990). Theories about life-history strategies suggest that a postponed reproduction may be favored if an increase of survival and fecundity with the increase of plant size occurs (Kachi \& Hirose 1985). However, in the case of the Paepalanthus polyanthus population studied, if mortality risks increase due to unpredictable risks of flooding, for instance, a delay in the reproduction could not be favorable. In Paepalanthus polyanthus, a smaller size for reproduction in flooded areas would be of interest as an important manner of escaping flooding. Despite the fact that only a few plants reached reproduction from 1990 to 1991 , the ones from the flooded Area 2 flowered younger with smaller diameters than those of Areas 1 and 3. This tendency is also described in relation to the sand dune grass Andropogon arenarius (Costa et al. 1988).

In the sand dune field studied, Paepalanthus polyanthus seems to behave as a short-lived monocarpic species. Although, in upland fields, submitted to other environmental factors, the species can behave as a long-lived monocarpic, with plants 
reaching an average life span of 28 years (Figueira 1998).

Acknowledgements - Financial support was provided by grants from DAP/UFSC and CNPq. We are grateful to Dr. Vera Lícia Vaz de Arruda and Dr. Benedito Cortês Lopes for suggestions on the study and comments on the manuscript. We are grateful to Lucir M. Locatelli for assistance in field sampling during 1987.

\section{References}

BOORMAN, L.A. \& FULLER, R.M. 1984. The comparative ecology of two sand dune biennials: Lactuca virosa $\mathrm{L}$. and Cynoglossum officinale L. New Phytologist 69:609-629.

BUCKLEY, R.C. 1982. Seed size and seedling establishment in tropical arid dunecrest plants. Biotropica 14:314-315.

CARVALHO, C.G.S. \& RIBEIRO, M.C. 1994. Efeito do armazenamento e de reguladores de crescimento na germinação de Paepalanthus speciosus, Eriocaulaceae. Revista Brasileira de Botânica 17:61-65.

CASTELLANI, T.T. 1990. Aspectos da ecologia reprodutiva de Paepalanthus polyanthus (Bong.) Kunth (Eriocaulaceae) nas dunas da Joaquina, Ilha de Santa Catarina, SC. In II Simpósio de ecossistemas da costa sul e sudeste brasileira: estrutura, função e manejo (ACIESP, ed.). Academia de Ciências do Estado de São Paulo (ACIESP), Águas de Lindóia, v.3, p.488-498.

CASTELLANI, T.T., FOLCHINI, R. \& SCHERER, K.Z. 1995a. Variação temporal da vegetação em um trecho de baixada úmida entre dunas, Praia da Joaquina, Florianópolis, SC. Insula 24:37-72.

CASTELLANI, T.T., SCHERER, K.Z., LOCATELLI, L.M. \& LOPES, B.C. 1995b. The occurrence of Junonia evarete (Lepidoptera: Nymphalidae) and Acromyrmex striatus (Hymenoptera: Formicidae) on Paepalanthus polyanthus (Eriocaulaceae). Journal of the New York Entomological Society 103:329-334.

CASTELLANI, T.T., VIEIRA, S. \& SCHERER, K.Z. 1996. Contribuição ao conhecimento da distribuição espacial de Paepalanthus polyanthus (Bong.) Kunth (Eriocaulaceae) em áreas de baixada úmida de dunas. Acta Botanica Brasilica 10:25-36.

CASTELLANI, T.T. \& D'EÇA-NEVES, F.F. 2000. Population ecology of Paepalanthus polyanthus: predispersal hazards and seed production. Acta Botanica Brasilica 14:317-326.

COSTA, C.S.B. \& SEELIGER, U. 1988. Demografia de folhas de Spartina ciliata Brong. em dunas e brejos costeiros. Revista Brasileira de Botânica 11:85-94.

COSTA, C.S.B., SEELIGER, U. \& CORDAZZO, C.V. 1988. Distribution and phenology of Andropogon arenarius Hackel on coastal dunes of Rio Grande do Sul, Brazil. Revista Brasileira de Biologia 48:527-536.

D'EÇA-NEVES, F.F. \& CASTELLANI, T.T. 1994. Fenologia e aspectos reprodutivos de Paepalanthus polyanthus (Bong.) Kunth (Eriocaulaceae) em baixada úmida entre dunas na Praia da Joaquina, Ilha de Santa Catarina, SC. Insula 23:121-149.
ERNST, W.H.O. 1981. Ecological implication of fruit variability in Phleum arenarium L., an annual dune grass. Flora 171:387-398.

FIGUEIRA, J.E.C. 1998. Dinâmica de populações de Paepalanthus polyanthus (Eriocaulaceae) na Serra do Cipó, MG. Tese de doutorado, Universidade Estadual de Campinas, Campinas.

GREIG-SMITH, P. 1983. Quantitative plant ecology. Backwell Scientific Publications, Oxford.

HARPER, J.L. 1977. Population biology of plants. Academic Press, London.

HUISKES, A.H.L. \& HARPER, J.L. 1979. The demography of leaves and tillers of Ammophila arenaria in a dune sere. Oecologia Plantarum 14:435-446.

HUTCHINGS, M.J. 1986. The structure of plant populations. In Plant ecology (M.J. Crawley, ed.). Blackwell Scientific Publications, Oxford, p.97-136.

JONG, T.J. \& KLINKHAMER, P.G.L. 1988. Population ecology of the biennials Cirsium vulgare and Cynoglossum officinale in a coastal sand-dune area. Journal of Ecology 76:366-382

KACHI, N. \& HIROSE, T. 1985. Population dynamics of Oenothera glazioviana in a sand-dune system with special reference to the adaptive significance of size-dependent reproduction. Journal of Ecology 73:887-901.

KLEMOW, K.M. \& RAYNAL, D.J. 1985. Demography of two facultative biennial plant species in an unproductive habitat. Journal of Ecology 73:147-167.

KLINKHAMER, P.G. \& JONG, T.J. 1988. The importance of small scale disturbance for seedling stablishment in Cirsium vulgare and Cynoglossum officinale. Journal of Ecology 76:383-392.

KLINKHAMER, P.G., JONG, T.J. \& MEIJDEN, E. VAN DER 1988. Production, dispersal and predation of seeds in the biennial Cirsium vulgare. Journal of Ecology 76:403-414.

MEIJDEN, E. VAN DER \& WAALS-KOOI, R.E. VAN DER 1979. The population ecology of Senecio jacobaea in sand dune system. Journal of Ecology 67:131-153.

MOLDENKE, H.N. \& SMITH, L.S. 1976. Eriocauláceas. In Flora ilustrada catarinense (R. Reitz, ed.). Herbário Barbosa Rodrigues, Itajaí, p.1-94.

SCHAT, H. \& SCHOLTEN, M. 1985. Comparative population ecology of dune slack species: the relation between population stability and germination behaviour in brackish environments. Vegetatio 61:189-195.

SOKAL, R.R. \& ROHLF, F.J. 1979. Biometria. H. Blume, Madrid.

SOUZA, M.L.R., FALKENBERG, D.B, AMARAL, L.A., FRONZA, M., ARAÚJO, A.C. \& SÁ, M.R. 1992. Vegetação do Pontal da Daniela, Florianópolis, SC, Brasil. I. Levantamento florístico e mapa fitogeográfico. Insula 21:87-117.

VAN BAALEN, J. \& PRINS, E.G.M. 1983. Growth and reproduction of Digitalis purpurea in different stages of succession. Oecologia 58:84-91.

VAN GROENENDAEL, J.M. 1986. Life history characteristics of two ecotypes of Plantago lanceolata L. Acta Botanica Neerlandica 35:71-86. 
WAECHTER, J.L. 1985. Aspectos ecológicos da vegetação de restinga no Rio Grande do Sul, Brasil. Comunicações do Museu de Ciências da PUCRS, Série Botânica 33:49-68.

WAITE, S. 1984. Changes in the demography of Plantago coronopus at two coastal sites. Journal of Ecology 72:809-826.

WALTER, H. 1986. Vegetação e zonas climáticas: Tratado de ecologia global. EPU, São Paulo.
WATKINSON, A.R. \& HARPER, J.L. 1978. The demography of a sand dune annual: Vulpia fasciculata. I: The natural regulation of populations. Journal of Ecology 66:15-33.

WERNER, P.A. 1975. Predictions of fate from rosette size in teasel (Dipsacus fullonum L.). Oecologia 20:197-201.

ZAR, J.H. 1974. Bioestatistical analysis. N. J. Prentice-Hall, Englewood Cliffs. 